\title{
Typology of Local Construction Materials from the Adamawa and North-West Regions of Cameroon
}

\author{
Zo'o Zame Philémon', Nzeukou Nzeugang Aubin ${ }^{2 *}$, Uphie Chinje Melo², \\ Mache Jacques Richard ${ }^{2}$, Ndifor Divine Azigui ${ }^{3}$, Nni Jean ${ }^{3}$ \\ ${ }^{1}$ Department of Earth Sciences, University of Yaoundé, Yaoundé, Cameroon \\ ${ }^{2}$ Local Materials Promotion Authority (MIPROMALO), Yaoundé, Cameroon \\ ${ }^{3}$ National Civil Engineering Laboratory (LABOGENIE), Yaoundé, Cameroon \\ Email: ${ }^{*}$ nzeuk@yahoo.fr
}

Received 2 March 2016; accepted 22 April 2016; published 25 April 2016

Copyright (C) 2016 by authors and Scientific Research Publishing Inc.

This work is licensed under the Creative Commons Attribution International License (CC BY). http://creativecommons.org/licenses/by/4.0/

(c) () Open Access

\begin{abstract}
This article summarizes the different local construction materials observed in two regions of Cameroon (Adamawa and North-West). These raw materials were mapped and evaluated using various methods of investigation (spatial distribution, estimation of reserves, development of a database compatible with geo-referenced maps). The results obtained show three types of local construction materials (vegetal, pedological and geological) with quantitative estimation or distribution. Vegetal local materials include herbaceous savanna with strong dominance of straw in Adamawa region than the North West region. Pedological local construction materials include lateritic soils (ferruginous or clayey), harplan, sandy clay and sandy clay soil while geological local construction materials include volcanic, plutonic and metamorphic rocks. Many sites of these geological materials are suitable for the rock quarry plant. Adamawa region also contains sedimentary rocks constituted by metamorphic conglomerate and sandstones. Two main types of residential homes are constructed with these local construction materials in these regions of Cameroon. These include huts and houses.
\end{abstract}

\section{Keywords}

Local Construction Materials, Typology, Adamawa and North-West Regions, Cameroon

\section{Introduction}

The term "construction materials" is used to describe all raw materials used by the construction industry, for

*Corresponding author.

How to cite this paper: Philémon, Z.Z., Aubin, N.N., Melo, U.C., Richard, M.J., Azigui, N.D. and Jean, N. (2016) Typology of Local Construction Materials from the Adamawa and North-West Regions of Cameroon. Geomaterials, 6, 50-59.

http://dx.doi.org/10.4236/gm.2016.62005 
example in road making or in house construction. Many construction materials and technologies have been adopted worldwide to build houses [1]. The choice of construction materials essentially depends on their suitability, their local availability and the amount of money you are prepared to invest. Building materials needs are important to the economy of the entire community, including that of the Southern countries that face for more than a decade a significant housing deficit [1].

The mapping project of local construction materials of Cameroon falls within the context of a circular letter $\mathrm{N}^{\circ}$ 002/CAB/PM of the Prime Minister on the 12th of March 2007 specifying the intensification of the use of local construction materials for public works especially public buildings and roads. It was placed under the auspices of the Ministry of Public Works, which is charged with the provision of funds for its execution. The Ministry on its turn lodged the project in the National Civil Engineering Laboratory to execute. This project is initiated basing on the premise that, Cameroon as a whole is endowed with enormous construction materials for public use, which are under exploited and not properly valorized [2] [3]. Thus, if these materials are identified, mapped out, categorized and valorized their use for constructions in specific localities, local economic conditions will prove very economical and effective. This will assist development planners in their regional development programmes whereby appropriate resources will be assigned to particular areas in respect to their local specificities. According to the reference terms, emphasis was in the use of remotely sensed data and GIS tools which generated a comprehensive inventory of these materials. These tools enabled the overlay of satellite images over existing ordnance survey maps in order to circumscribe the different council areas [3]. In this wise, the potentials of local construction materials for each council area could be identified and mapped out. This article therefore focuses on the activities and results obtained.

\section{Summary Presentation of the Two Regions}

The Adamawa and North West regions (Figure 1) are on the administrative plan, divided into 05 and 07 Divisions

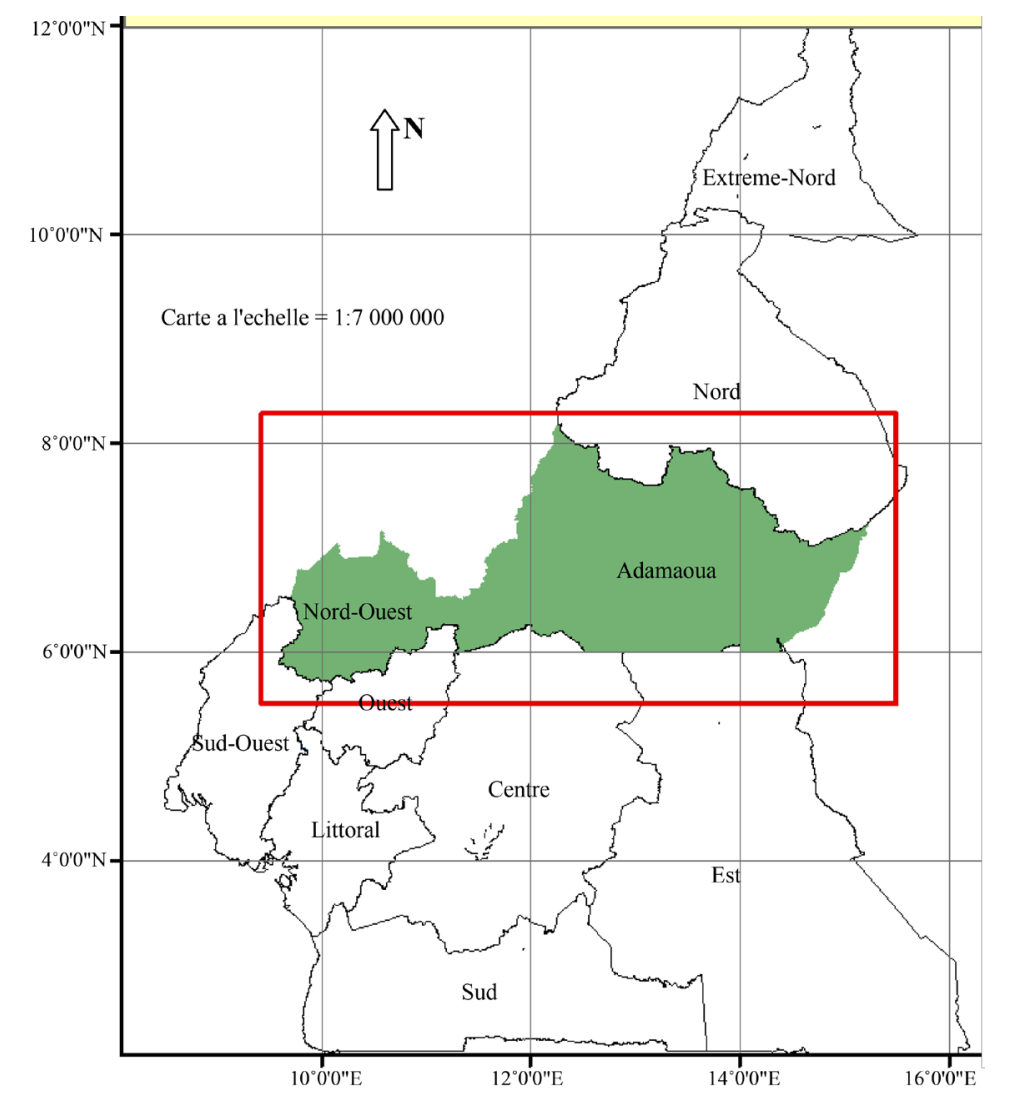

Figure 1. Localization of the two regions studied Adamawa (AD) and North West $(\mathrm{NW})$ in [3]. 
respectively. They are Djerem, Faro et Deo, Mayo Banyo, Mbéré and Vina for the Adamawa region; Boyo, Bui, Donga Mantung, Mentchum, Mezam, Momo and Ngoketunjia for the North West region. The respective capital of the two regions is Ngaoundéré and Bamenda.

The Adamawa region is a vast plateau with gentle slope to the south and steep sides at the north, with geographical coordinates $13^{\circ} 30^{\prime} 0$ "E and $06^{\circ} 30^{\prime} 0^{\prime \prime} \mathrm{N}$. The average elevation is $914 \mathrm{~m}$. From south to north, altitudes increase slowly and in a regular manner until around Meiganga where it begins at the Adamawa plateau with elevations between 1000 and $2000 \mathrm{~m}$. The most important mountains are: Guenfalabo, Tchabal Mbabo (2460 m) and Hossere Djinga Nganha (1923 m). On the tectonics plan, the region belongs to the Panafrican belt [4].

The North-West region of the Republic of Cameroon is located along the Cameroon Volcanic Line which is part of an extinct volcanic center of the west Cameroon highlands. Its belongs to the West Cameroon Highlands with the most important mountain massive like Mt. Bambouto $(2710 \mathrm{~m})$ at south and the Mt. Oku $(3008 \mathrm{~m})$ at north. Major's series of crater lakes are Lake Nyos, Wum, Oku, and Awing amongst others. This region is localized at $10^{\circ} 08^{\prime} 45^{\prime \prime} \mathrm{E}$ and $05^{\circ} 57^{\prime} 34 " \mathrm{E}$; the elevation above the sea level is $1410 \mathrm{~m}$. The region is constituted mainly of basalt (85\%), plutonic rock (5\%), metamorphic basement $(5 \%)$ and sedimentary rock $(5 \%)$. These formations are the main local materials of geological origin of this region [5]. The top soil which in mainly laterite, has favourable geotechnical characteristics for the fabrication of building bricks.

\section{Methods and Techniques}

In the methodological point of view, four steps were made in order to achieve our objectives: data collection, image treatment and interpretation, the search of locations of sites and the estimation of average volume (Figure 2).

For Data collection, two different means were used to acquire the data needed for this project. Firstly, there was documentary consultation where the results of previous works, especially the scientific publications on pedology and geology for the Adamawa were consulted. Secondly there was the use of remote sensed data. With this, multi-band, multi-date and multi-spectral SPOT 5 satellite images were provided by the Ministry of Public Works. These images had been purchased from the ASTRIUM Group, an enterprise based in France. The images ranged from 2005 to 2010 and in order to resolve the problem of the infra-red band, SPOT 4 satellite image with a resolution of $10 \mathrm{~m}$ grouping 91 scenes in one mosaic was added.

Surfaces of at least $100 \mathrm{~m}^{2}$ that were preliminarily identified basing on pre-knowledge of the region served as references for sampling and classification with the Erdas computer software in image treatment and interpretation. Using image enhancements, iteration and the different adaptive filters for respective purposes (Lee, Frost, Gamma, Kuan) to interpret both surface and subsoil characteristics, three classified images were obtained-vegetal, pedological and geological formations. To validate these classifications, an intensive fieldwork was organized which lasted for 65 days. During the fieldwork, verifications of the different formations revealed by the image treatment had to be made, pits were dug using pick axes and spades to determine the thickness of some superficial formations, quarry positions, natural and planted forests (eucalyptus forest), Indian and raffia bamboo sites, outcrops of granitic and plutonic rocks were all located with the use of GPS. For accuracy purposes,

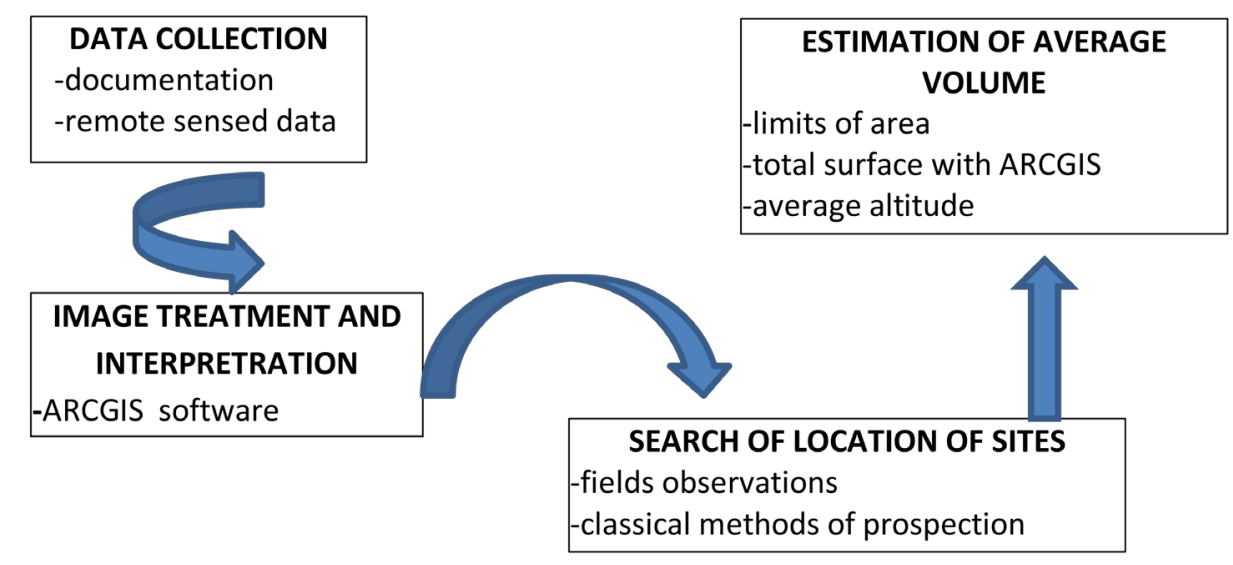

Figure 2. Flow chart of the methodology used. 
control points were taken so as to geo-reference the existing ordnance survey maps that bears the administrative units of the region. Having the ordnance survey maps geo-referenced, the treated and validated satellite images in raster layers were then converted to vector layers in order to have them opened in the ArcGIS software. In the ArcGIS, the treated image was then superimposed on the geo-referenced survey map that contained all the administrative units of the region. This was done following the different types of local construction materials identified in the region. To this effect, the vector layers of geological, pedological and vegetal formations were overlaid on the survey map one after the other so as to easily map out and determine the volumes of construction materials in each council area.

The search and location of the sites of local construction materials is based on field observations and the use of empirical methods of investigations. All the different types of local materials were sampled and all the exploitation sites located with use of GPS. In the field, pedological, geological and plant formations sites were identified and located.

The estimation of the average volumes of soil and rock formations, consisted of determining the limits of each material type, the total surface area of that material type (done in square meters) within ArcGIS and the average altitude using contours. The average volumes of the materials that can be extracted $\left(V_{m}\right)$ is a function of the average force $\left(F_{m}\right)$ and the surface $(S)$ following this equation:

$$
V_{m}=F_{m} \times S
$$

With $F_{m}$ in meters, $S$ in square meters and $V_{m}$ in cubic meters.

\section{Results}

Three types of raw materials are observed which include vegetation, soils and rocks. All the types of vegetation identified are limited to those used for construction by the local communities (i.e.: wood, bamboo, straw...). Pedological and geological formations observed in the field are classified depending of their nature. For soils, we had noted the texture (visual granulometry) to know if the grain is fine or coarse, the color, the plasticity and topology of location (hill, valley or swam area) to differentiate clay from laterite, etc. Literature has also helped us to know the geological formation which dominates in each area. The synthesis below is related to some information about each type of raw material and their uses in construction

\subsection{Vegetal Local Construction Materials}

A number of local construction materials were identified and mapped out in the two Regions which differ to an extent from one council area to the other (Figure 3). In the Adamawa region, 338 sites have been localized and we have straw, raffia bamboo and rarely china bamboo, eucalyptus wood type and fir. In North-West region, 190 sites have been localized and we especially observed the eucalyptus wood type, the raffia bamboo and china bamboo and rarely straw. All the types of vegetation identified are represented in all the divisions but the division with the most natural vegetation is Vina with about $24.55 \%$ of natural vegetation in the whole region and Donga Mantung with about 37.64\% in Adamawa and North-West regions respectively [2] [3].

The huts constructed with these raw materials (bamboo and wood) are mostly found in chief's palaces or in some ritual constructions [2] [3]. These types of modest homes today portray cultural and anthropological relics of the people. The architecture respects some geometry in the spacing of the local construction materials used. With these types of huts, there is a stone foundation which is deep into the ground. The walls are made of raffia bamboos which are tied together following a well-structured architecture. The doors and windows are equally made of raffia bamboos. The rafters often in conical form are supported by strong eucalyptus pegs. The roof, made up of grass, covers the whole building. With wood, there is no foundation; they have walls constructed with sawn eucalyptus planks. The rafters mostly in two slopes are supported by strong wood pillars and the roofs covered by corrugated iron sheets. Most of the wood used is untreated thereby being vulnerable to insect attack, humidity and rotting. Being of recent appearance, these types of huts are mostly found in market places [2] [3].

\subsection{Pedological Formation for Local Construction Materials}

Pedological formations of the Adamawa region are clays, alluvium sands and rarely of plain, arena (clayey sand and sandy soils), lateritic soils (laterites, graves and hardpan). In the NW Region, we have clays, alluvial and 


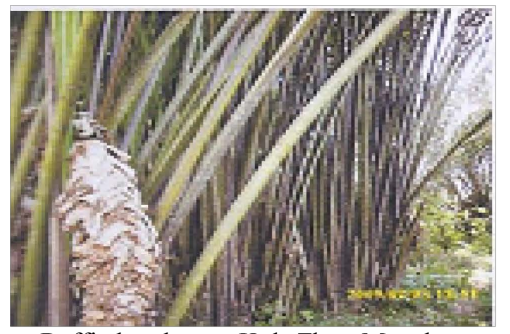

Raffia bamboo at Kuk-Zhoa-Menchum

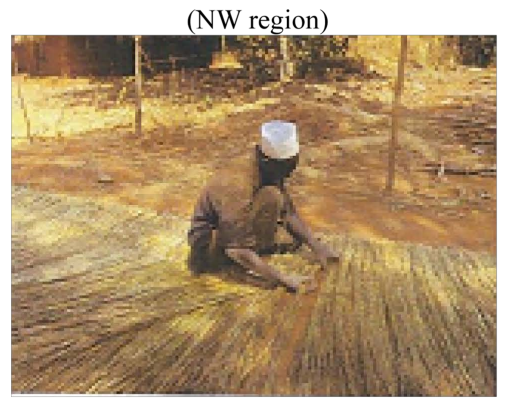

Hancraft making of mat at Biskewal

Ngaoundéré 2-Vina (Adamawa region)

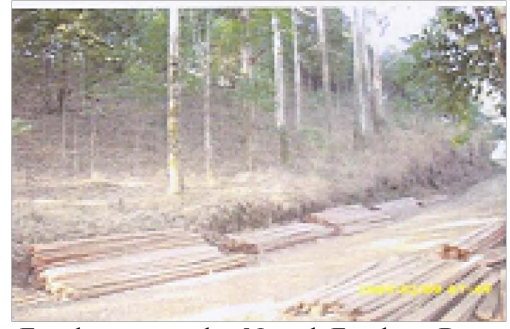

Eucalyptus wood at Ngwah Fundong-Boyo (NW region)

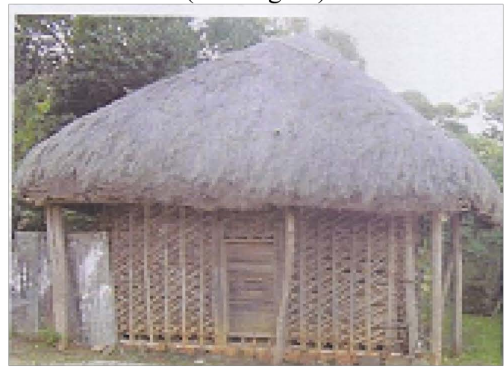

Ndu palace in bamboo-Ndonga Mantung (NW region)

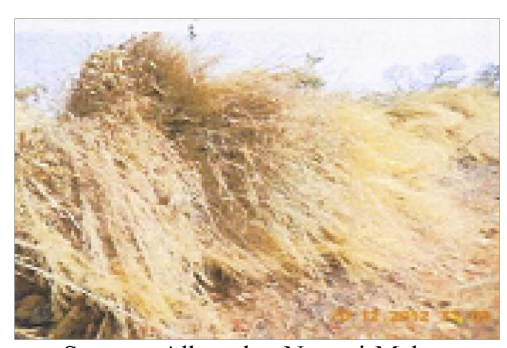

Straw at Alhamdou Ngaoui-Mebere (Adamawa region)

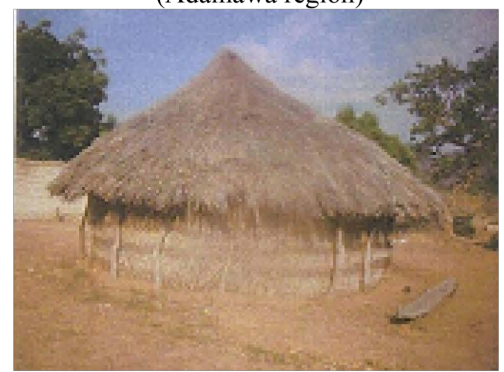

Hut in mat Lac quarter Tignère-Faro et Deo (Adamawa region)

Figure 3. Major types of vegetal local construction materials observed.

plain sands, arena (clayey sand and sandy soils), lateritic soils (laterites, graves and harplan) and little differentiated soils developed on volcanic rocks (pyroclasts in early weathering) (Figures 4-6).

\subsubsection{Clays}

Clays are the weathered materials from rocks (Figure 4(a) and Figure 4(b)). The clays observed in the Adamawa region are localized in 76 sites in which 24 are under exploitation. We can estimate about $141,000,000 \mathrm{~m}^{3}$ of clays available in these sites (Table 1). In the NW region, they are whitish, black greyish, reddish or yellowish and even violet colour, and these rocks are often covered by lateritic clay or lateritic gravel. 73 sites have been localized and 12 are under exploitation. For guidance, most of $903,000 \mathrm{~m}^{3}$ of clay can be exploited in that 73 sites observed. We estimated that they occupy about $1665 \mathrm{~km}^{2}$ of surface area being $8.05 \%$ of the whole region [2] [3]. These clays can be used to produce floor tiles and pavers (Figure 4(c)) or clay earth blocks (Figure 4(d)).

\subsubsection{Alluvial and Plain Sand}

They are found either in the form of flats in river beds or in hard deposits. Its colour ranges from grey to dark grey, red or black. It can be fine with a high proportion of clay or limon particles, average or coarse with mineral composition of quartz, feldspar or sometimes ferruginous or other rock fragments. 113 sites with 45 under exploitation have been found in the Adamawa region against 106 sites with 47 under exploitation in the North West region (Figures 4(e)-(g)). The surface area they occupy is estimated at about 195,513,005 $\mathrm{m}^{2}$ being $0.94 \%$ of all the soils in the NW Region [2] [3]. These sands can be used to produce balusters, concrete pavers (Figure 4(h)) or concrete blocks (Figure 4(i)).

\subsubsection{Clayey Sand and Sandy Soils}

Clay sandy soils are bullrings. They constitute thick layers of alterites which lie directly on plutonic and metamorphic rocks from where they were derived. They are either covered by low layers of clay laterite or gravel. They are usually light in colour looking dusty or red (Figure 4(j) and Figure 4(k)). The effects of erosion are very visible in zones where it is well developed. In the Adamawa region, 102 sites with 05 under exploitation have been localized. The average total volume is $488,900,000 \mathrm{~m}^{3}$. In the North West region, 62 sites with 12 under exploitation have been localized (Table 1). The average volume is $237,000 \mathrm{~m}^{3}$. They are absent in volcanic landscape and found all over the western part of the NW region and being $23.41 \%$ of all the soils in the region [2] [3]. 


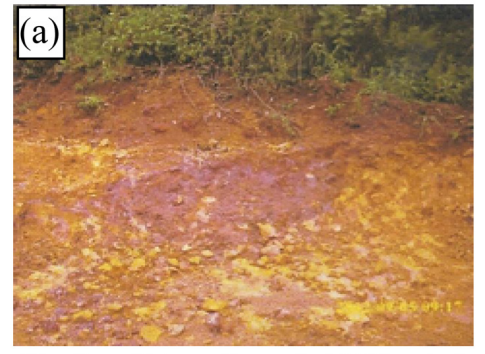

Clay from Alateneg Bamenda 1 (NW region)

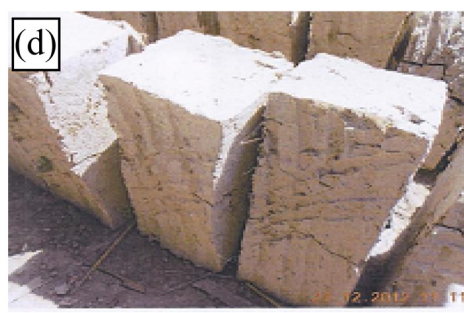

Handcraft production of clay earth bloc-Dir Mbéré (Adamawa region)

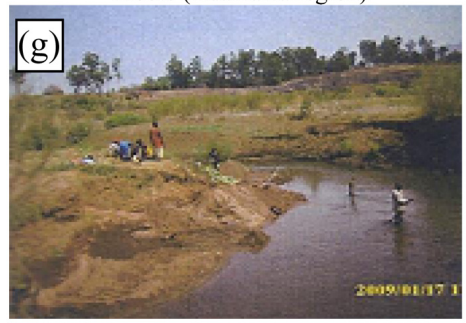

Exploitation of sand from Mbim river -NkorBui (NW region)

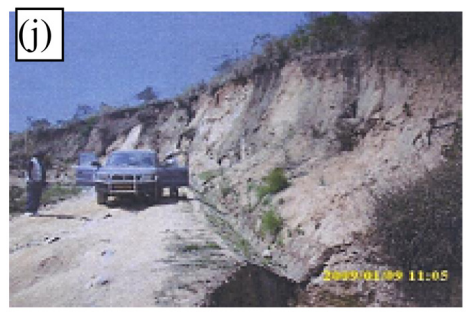

Sandy soil from Rom village-Nwa-Donga Mantung (NW region)

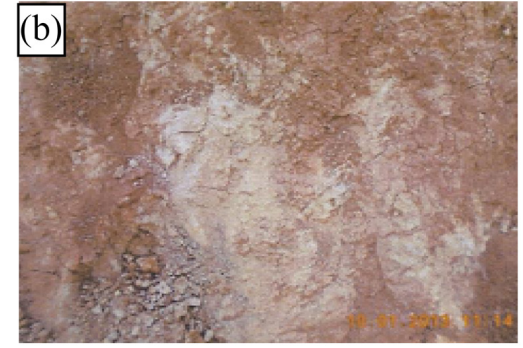

Clay from Foufouké (Adamawa region)

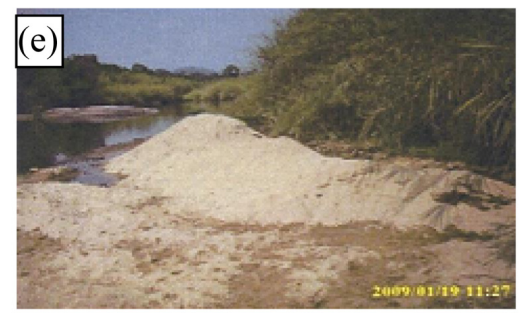

Sand from Akong river -Ako-Donga Mantum (NW region)

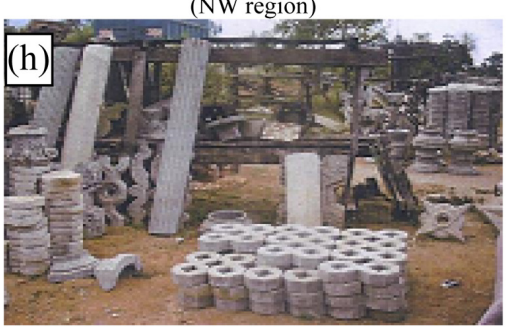

Production of balusterd, concrete pavers -NkwenBamenda 3-Mezam (NW region)

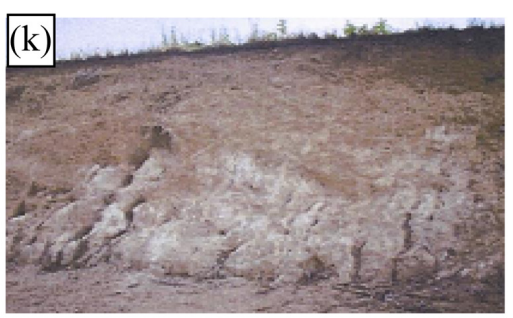

Sandy soil from Mbamti Katarko-Mayo Banyo (Adamawa region)

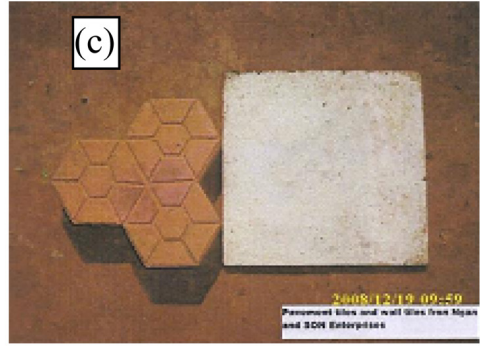

Semi industril unit of floor tiles and pavers with clay raw material by Ste NGAN \& SONS Bamenda 1 (NW region)

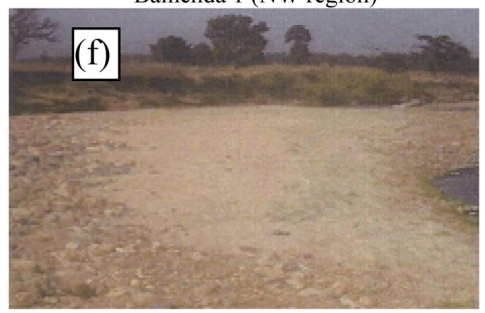

Sand from Mayo Baléo-Faro et Deo (Adamawa region)

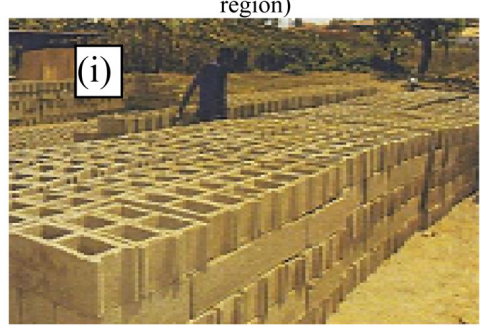

Production of concrete blocs at carrefour Norvegien-Ngaoundéré 3-Vina (Adamawa

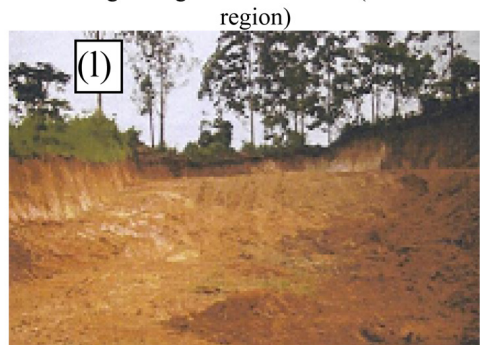

Clayey laterite from Tubah Centre-Mezam (NW region)

Figure 4. Major pedological (clays and alluvial sand) formations for local construction materials observed.

\subsubsection{Laterites}

They are two types of lateritic soils (lateritic clayey or lateritic gravels). Laterites soils are red or brown (Figure 4(I) and Figure 5(m)). They exist in abundance in all the divisions of regions. They are homogenous soils and result from the weathering of volcanic rocks and to a limited extent from plutonic and metamorphic soils. They are sometimes associated with lateritic gravels. 275 sites with 64 under exploitation have been located in the Adamawa region. The average volume is $918,000,000 \mathrm{~m}^{3}$. For the North West region, 170 sites have been located with 34 under exploitation. The average volume for this region is $694,800 \mathrm{~m}^{3}$ (Table 1).

The lateritic gravels in contrary to laterite clayey are heterogenous red soils and are either constituted of granules, pisolites or fragments of the mother rock, hardpan or minerals especially quartz found within clay (Figure 5(n) and Figure 5(0)). 354 sites with 99 under exploitation have been located in the Adamawa region. The average volume is $1,378,000,000 \mathrm{~m}^{3}$. For the North West region, 155 sites have been located with 53 under exploitation. The average volume for this region is $408,800 \mathrm{~m}^{3}$ (Table 1). In the whole NW region, the estimated 


\section{Z. Z. Philémon et al.}

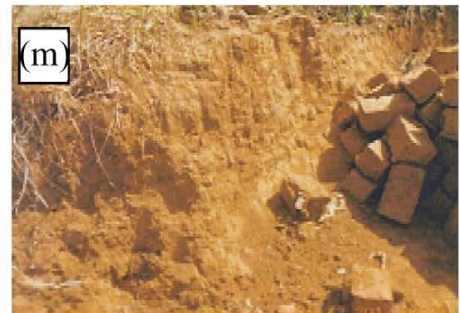

Clayey laterite from Wakaso-Dir-Meiganga (Adamawa region)

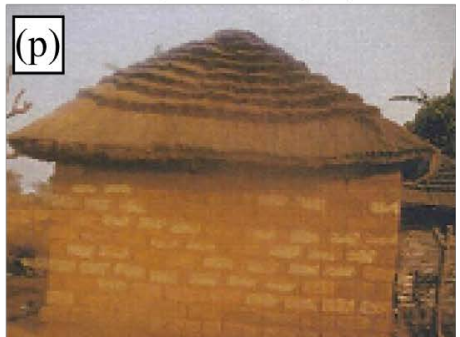

House with compressed earth block with roof with straw-Bangam-Tibati-Djerem (Adamawa region)

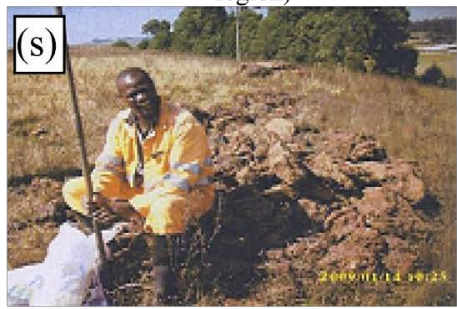

Harplan from Tatum-Nkum-Bui (NW region)

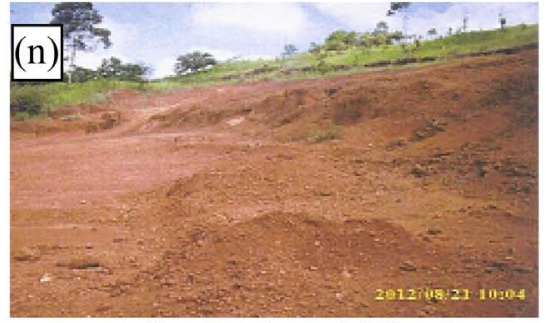

Gravels under exploitation at Nkontang-Bali-Mezam (NW region)

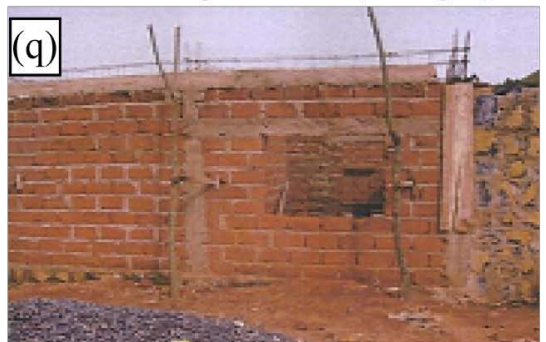

House in construction with wall in Compressed earth block-Tubah-Mezam (NW region)

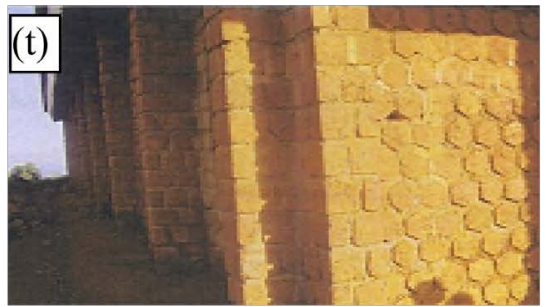

House built with harplan bloc-Tatum-Nkum-Bui (NW region)

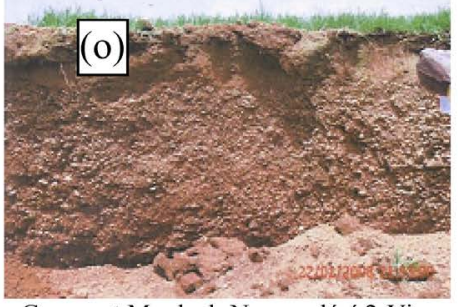

Graves at Mardock-Ngaoundéré 2-Vina (Adamawa region)

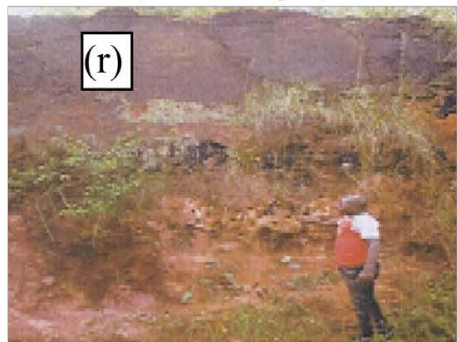

Harplan along the Dir-Meiganga road-Mbéré (Adamawa region)

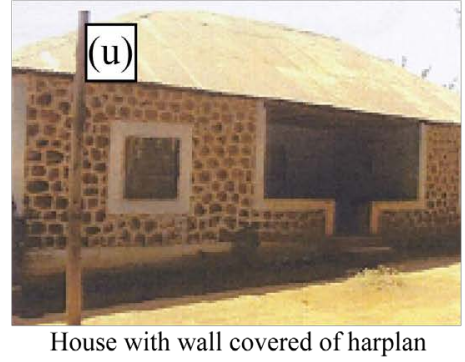

blocks-Ngaoundéré-Vina (Adamawa region)

Figure 5. Major pedological (clayey soils and laterites) formations for local construction materials observed.

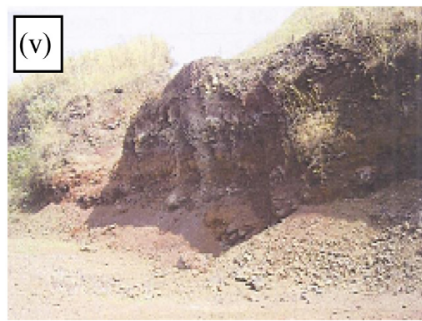

Consolidated volcanic blocks-Befang-Benakum Menchum (NW region)

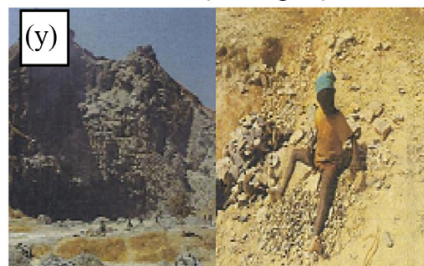

Quarry of phonolite-Beka-Tegeren-Ngaoundéré 3 -Vina and handcraft production of gravels at Ngaounsaie-Ngaoundéré 2- Vina (Adamawa region)

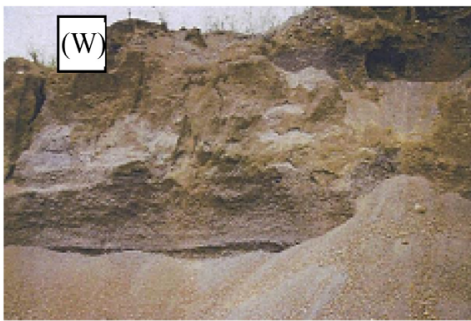

Pouzzolan at Bangwe-Benakuma Menchum (NW region)

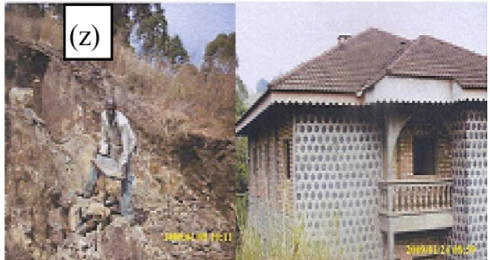

Quarry of basalt from Ndu-donga Mantung and walls of house decorated with stones at Kumbo-Bui (NW region)
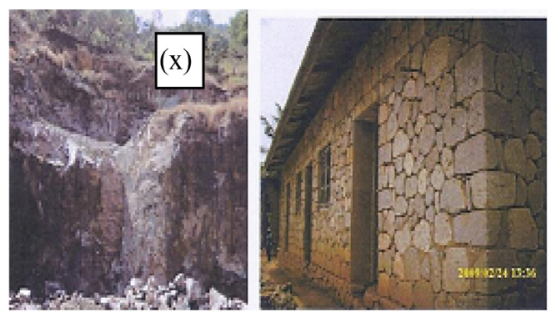

Quarry of granit from Mt Ngaoundal (Adamawa region) and house built with dimentioned stone-Bamenda 2 (NW region)

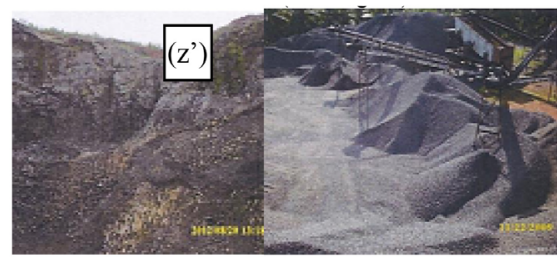

Quarry of basalt and industrial production unit of gravels at Grass Camp-Widikum-Momo (NW region)

Figure 6. Major geological formations for local construction materials observed. 
Table 1. Total volume $\left(\mathrm{m}^{3}\right)$ of soil types per division in the Adamawa and north west regions.

\begin{tabular}{|c|c|c|c|c|c|c|c|}
\hline \multirow{2}{*}{ Types of soil } & \multicolumn{7}{|c|}{ Adamawa region } \\
\hline & Djerem & \multicolumn{2}{|c|}{ Faro et Deo } & \multicolumn{2}{|l|}{ Mayo Banyo } & Mbéré & Vina \\
\hline Clay & $4,200,000$ & \multicolumn{2}{|c|}{$7,600,000$} & \multicolumn{2}{|c|}{$100,800,000$} & $17,270,000$ & $11,000,000$ \\
\hline $\begin{array}{c}\text { Alluvial and plain } \\
\text { sand }\end{array}$ & - & \multicolumn{2}{|c|}{-} & \multicolumn{2}{|c|}{-} & - & - \\
\hline Clay sand soil & $3,900,000$ & \multicolumn{2}{|c|}{$16,000,000$} & \multicolumn{2}{|c|}{$266,000,000$} & $78,000,000$ & $125,000,000$ \\
\hline Volcanic soil & - & \multicolumn{2}{|c|}{-} & \multicolumn{2}{|c|}{-} & - & $12,000,000$ \\
\hline Lateritic clay & $58,000,000$ & \multicolumn{2}{|c|}{$383,000,000$} & \multicolumn{2}{|c|}{$97,000,000$} & $154,000,000$ & $226,000,000$ \\
\hline Gravel & $387,000,000$ & \multicolumn{2}{|c|}{$292,000,000$} & \multicolumn{2}{|c|}{$330,000,000$} & $40,000,000$ & $329,000,000$ \\
\hline \multirow[t]{3}{*}{ Hardplan } & $112,000,000$ & \multicolumn{2}{|c|}{$35,000,000$} & \multicolumn{2}{|c|}{500,000} & $76,000,000$ & $398,000,000$ \\
\hline & \multicolumn{7}{|c|}{ North west region } \\
\hline & Boyo & Bui & $\begin{array}{c}\text { Donga } \\
\text { Mantung }\end{array}$ & Mentchum & Mezam & Momo & Ngokketunjia \\
\hline Clay & 273,000 & 194,000 & 4000 & 12,000 & 313,000 & 37,000 & 68,000 \\
\hline $\begin{array}{c}\text { Alluvial and plain } \\
\text { sand }\end{array}$ & - & - & - & - & - & - & - \\
\hline Clay sand soil & - & 20,000 & - & 26,000 & 32,000 & 145,000 & 14,000 \\
\hline Volcanic soil & - & - & - & 54,000 & - & - & - \\
\hline Lateritic clay & 29,800 & 225,000 & 48,000 & 26,000 & 109,000 & 112,000 & 145,000 \\
\hline Gravel & 18,800 & 66,000 & 20,000 & 90,000 & 96,000 & 85,000 & 33,000 \\
\hline Hardplan & - & 2,000 & - & - & - & - & - \\
\hline
\end{tabular}

surface of lateritic clayey soils is $8,919,500,935 \mathrm{~m}^{2}$ being $43.11 \%$ of all the soils in the Region and the lateritic gravel occupies an estimated surface area of $2,936,368,821 \mathrm{~m}^{2}$, being $14.19 \%$ of all the soils in the NW Region [2] [3].

The types of mud houses constructed with lateritic soils represent about $5 \%$ of all the houses in the North West Region [2] [3]. They are mostly found in villages far off the major towns. These houses are made up of thatches that are filled with mud. The foundation is made of a large stone. This stone is placed on another one and are held together by laterite or clay mortar. For guidance, the brick houses are the most popular houses in the whole North West Region (about 45\%). These houses can be divided into two types: Brick houses with grass roof (Figure 5(p)) and Brick houses with corrugated iron sheet roof (Figure 5(q)). Most of these houses have their foundations built in large shaped stones. The walls of these houses are constructed sun dried bricks placed on one another sometime following the present construction norms and held together by laterite and clay mortar. The doors and windows are either made of eucalyptus wood or glass. Besides the stone houses the other sub types present long term disadvantages especially due to erosion and alternation of the dry and rainy seasons. To overcome inconveniences, the walls of some of these house scan be plastered with concrete or reinforced by concrete pillars.

\subsubsection{Hardpans}

Lateritic hardpans according to [6] are hard soils (Figure 5(r) and Figure 5(s)). 56 sites with 03 under exploitation have been located in the Adamawa region. The average volume is $626,000,000 \mathrm{~m}^{3}$. For the North West region, only 05 sites have been located with 02 under exploitation. The average volume for this region is $2000 \mathrm{~m}^{3}$ in Bui Division (Table 1). Large deposits of hardpans have been identified in Donga Mantung Division, especially in the north of the Ako council are right to Abonshe at the frontier with Nigeria. They can also be found at the base of lateritic clay or lateritic gravel in the north of Nkum council area in Bui Division. They occupy an estimated area of $1,979,487,672 \mathrm{~m}^{2}$ being $9.57 \%$ of all the soils in the region [2] [3]. These local materials can 
be used to building houses as block (Figure 5(t)) or as wall decoration (Figure 5(u)).

\subsubsection{Volcanic Soils}

Volcanic soils are either pyroclastic product which is at the early or advanced stage of weathering (pouzzolans, blocs, scories, etc...) (Figure 6(v) and Figure 6(w)). Sometimes they are constituted of low stratified deposits of pouzzolane (mixture of blocs, rock fragments and scories) around the crater lakes. 09 sites have been located in the Adamawa region. The average volume is $12,000,000 \mathrm{~m}^{3}$. For the North West region, 23 sites have been located with 02 under exploitation. The average volume for this region is $54,000 \mathrm{~m}^{3}$ (Table 1). In this region, they can mostly be identified in Menchum Division and in low quantities in the divisions of Boyo, Bui, Donga Mantung and Mezam. They occupy an estimated surface area of $149,878,267 \mathrm{~m}^{2}$ being $0.72 \%$ of all the soils in the NW Region [2] [3].

\subsection{Geological Formations}

Geological formations observed in this two regions comprise: volcanic, plutonic, metamorphic and sedimentary rocks (Figure 6(x) to Figure 6( $\left.\mathrm{z}^{9}\right)$ ). 217 sites with 23 under exploitation have been located in the Adamawa region. The average volume is $75,197,000,000 \mathrm{~m}^{3}$. For the North West region, 224 sites have been located with 61 under exploitation. The average volume for this region is $30,558,000 \mathrm{~m}^{3}$ (Table 2).

Volcanic rocks belong to the volcanic formations of the Cameroon Volcanic Line [6] [7]. They appear in the form of domes and flow domes, cones of high accumulation of basalt, trachyte and phonolite. They are being released from metamorphic and granitic formations. Pyroclastic products (volcanic rocks) are found at the immediate surroundings of crater lakes where they are associated with cones and less extensive basalt formations. In the Adamawa region, they are found at department of Faro et Deo (Galim Tignere, Mayo Baleo, Tignere), Mayo Banyo (Banyo), Mbere (Meiganga, Djohong), and Vina (Belel, Nganha, Nyambaka, Ngaoundere 1, 2 and 3 ). At the North West region, they occupy an estimated area of $4,637,791,377 \mathrm{~m}^{2}$, being $29.18 \%$ of all the rocks in the region [2] [3].

Plutonic rocks are intrusive rocks found within orthogneiss, gneiss and migmatites. They are mostly coarse grain granite of pink or white feldspaths and scarcely diorites. They are identified in the form of north north eastsouth south west elongated bands at the western region of the limit of Nigeria republic, either in the central and southern part of the Adamawa region. In the North West region, they form a large massif in the central part of the region covering especially the councils of Zhoa and Furu Awa; the whole of Fonfuka council and more than half of the southern Misaje council. These plutonic rocks also cover the whole eastern part of the Ako and Nwa councils and ends in the east of the Mbiame and Nkambe councils. They occupy an estimated area of 4,595,474 $961 \mathrm{~m}^{2}$, being $28.91 \%$ of all the rocks in the region [2] [3].

Metamorphic rocks constitute the substratum of the two Regions. They are orthogneiss, gneiss and migmatites on which slabs of amphibolites appear. Some dykes of dolerite are also present. In the Adamawa region, they are from a north north east-south south west elongated bands in alternance with the plutonic rocks. These types of rocks show a great variety in structure and composition and properties. In the North West, the plutonic rocks have intruded into the metamorphic rocks and in some places they are covered by volcanic rocks that stretch from Batibo in the SW to Nkambe in the NE passing through Bamenda, Belo, Fundong, Elak, Jakiri, Kumbo,

Table 2. Estimated volumes of geological formations.

\begin{tabular}{cccc}
\hline $\begin{array}{c}\text { Division } \\
\text { (North West region) }\end{array}$ & Rocks $\left(\mathbf{m}^{\mathbf{3}}\right)$ & Division (Adamawa region) & ${\text { Rocks }\left(\mathbf{m}^{\mathbf{3}}\right)}^{\text {B }}$ \\
\hline Boyo & $5,200,000$ & Djerem & $5,700,000,000$ \\
Bui & $5,100,000$ & Faro et Déo & $11,780,000,000$ \\
Donga Mantung & $4,400,000$ & Mayo Banyo & Mbéré \\
Mentchum & $4,600,000$ & Vina & $29,550,000,000$ \\
Mezam & $4,400,000$ & - & - \\
Momo & $5,900,000$ & - & - \\
\hline
\end{tabular}


Nkum and Ndu. They occupy a surface area estimated at $6,661,922,855 \mathrm{~m}^{2}$, being $41.91 \%$ of all the rocks in the region [2] [3].

Sedimentary rocks are constituted by metamorphic conglomerate and sandstones. They are localized in Kontcha basin, Djerem ditch near Ngaou Hills in Ngouandal municipality, Mbere ditch crossing some localities: Nyambaka, Meiganga, Belel, Djohong following a south south west-nord nord east orientated band constitute the greatest variation in strength and behavior.

The use of stones for construction in these two regions date back to the colonial period. Some still exist today and they have undergone light modifications in the arrangement of the structure. In these houses, the foundations and walls are a continuous set up that is very resistant (Figure 5(t), Figure 6(x) and Figure 6(z)). The dimensions and the forms of these blocks can either be variable when they have been shaped with a hammer or almost identical when the blocks have been sawn. These blocks are placed one after another and are held together by clay during the colonial era and today by concrete. The doors of these houses are mostly in wood. Rafters are made sawn planks which support roof made of corrugated iron sheets. Most of these houses are the remains of colonization and are better represented through churches or other religious establishments due to the high cost of shaped stones; this construction technique has greatly lost grounds giving way to more solid modern houses. The semi bloc houses are of recent creation. They can be found in all the divisions of the North West Region with an average of about $45 \%$ of all the houses of the region [2] [3]. All these houses are constructed with well dug foundations and these foundations are built with stones that sometimes attain $30 \mathrm{~cm}$ in size. These stones are held together by mixed cement and the solidity of the structure is reinforced by pillars and iron rods.

\section{Conclusion}

The raw materials of the two regions in Cameroon (Adamawa and North-West) include different easily exploitable types for building industries. Plant materials are constituted by a straw and raffia bamboo in the Adamawa region. In North-West region, we especially observed the eucalyptus wood type, the raffia bamboo and china bamboo and rarely straw. The pedological local construction materials are constituted of clays $\left(141,000,000 \mathrm{~m}^{3}\right)$, Alluvial and plain sand, clay sandy soils $\left(488,900,000 \mathrm{~m}^{3}\right)$, clay laterites $\left(918,000,000 \mathrm{~m}^{3}\right)$, gravel $\left(408,800 \mathrm{~m}^{3}\right)$, lateritic hardpans $\left(626,000,000 \mathrm{~m}^{3}\right)$ and volcanic soils $\left(12,000,000 \mathrm{~m}^{3}\right)$. Geological formations include volcanic rocks $(29.18 \%)$, plutonic rocks $(28.91 \%)$ and metamorphic rocks $(41.91 \%)$. Two main types of residential homes are constructed with these local construction materials. These include huts (Grass, Bamboo and Wood) and houses (Mud, Brick, Stone and Semi bloc).

\section{References}

[1] Njoya, A., Nzeukou, A., Mache, R.J., Wetshondo, D., Pirard, É., Melo, C.U. and Fagel, N. (2015) Valorisation des géoressources pour matériaux locaux de construction en zone périurbaine des pays en voie de développement. In: Bogaert, J. and Halleux, J.-M., Territoires périurbains. Développement, enjeux et perspectives dans les pays du Sud, Presses agronomiques de Gembloux, Gembloux, 141-149.

[2] Kah, E. and Ndifor, A. (2013) Mapping of Local Construction Materials for the North West Region of Cameroon. Proceedings of the 26th International Cartographic Conference (ICACI Organization), 25-30 August 2013, Dresden, $256 \mathrm{p}$.

[3] MINTP (2013) Cartographie des matériaux locaux dans les régions de l'Adamaoua. Phase Conditionnelle No. 1, 2010, 2012, 2013, $458 \mathrm{p}$.

[4] Lasserre, M. (1958) Etude géologique de la partie orientale de l'Adamaoua (Cameroun central) et les principales sources minéralisées de l'Adamaoua. Thèse Faculté des Sciences de Clermont Ferrand, 273 p.

[5] Njilah, K.I. (1991) Geochemistry and Petro Genesis of Tertiary-Quaternary Volcanic Rocks from Oku-Ndu Area, NW Cameroon. Doctorat PhD, University Leeds, $345 \mathrm{p}$.

[6] Lissom, J. (1991) Etude pétrographique des laves alcalines du massif d'Oku: Un ensemble volcanique de la ligne du Cameroun. Th. Univ. Pierre et Marie Curie (Paris VI), 207 p.

[7] Nni, J. (2004) Magmatogenèse du versant Sud-Ouest des monts Bamenda-Bambouto (ligne du Cameroun). Géologie, Volcanologie et Pétrogenèse, Th. d'Et. Univ. Ydé 1, 208 p. 